\title{
Improvement in a human IgE-inducing system by in vitro immunization
}

\author{
Shuichi Hashizume ${ }^{1 *}$, Hiroharu Kawahara ${ }^{2}$ \\ From 23rd European Society for Animal Cell Technology (ESACT) Meeting: Better Cells for Better Health \\ Lille, France. 23-26 June 2013
}

\section{Introduction}

The immune system, which is the self-defense system of the body, occasionally responds in a manner that is harmful to the body. The incidence and severity of allergies caused by cedar pollen, house dust, egg protein, and many others are increasing and have recently become a serious social problem. We have previously developed an original in vitro system for inducing human IgE antibody specific to a designated antigen that can be used to study various allergic reaction [1]. In this study, we attempted to improve this system to stimulate IgE levels in its medium to provide a highly sensitive screening method.

\section{Experimental}

The original in vitro IgE-inducing system was established using lymphocytes and plasma from donors which were not naturally immunized with allergens. The original system contained ERDF supplemented with fetal bovine serum (final concentration, 5\%) and contained human plasma (10\%) as an essential component. Human peripheral blood lymphocytes and plasma were obtained by density-gradient centrifugation at $400 \times \mathrm{g}$ for $30 \mathrm{~min}$ with cell separation medium, Ficoll-Paque ${ }^{\mathrm{TM}}$ Plus. This system also included allergen $(100 \mathrm{ng} / \mathrm{ml})$, interleukins (IL-) 2, 4, and 6 (10 ng/ml each) and muramyl dipeptide (MDP, $10 \mu \mathrm{g} / \mathrm{ml}$ ), as described previously [2]. Human lymphocytes were cultured in 96- or 24-well plates at a final density of $1 \times 10^{6} \mathrm{cells} / \mathrm{ml}$ in the medium and incubated in a $\mathrm{CO}_{2}$ incubator at $37^{\circ} \mathrm{C}$ for 10 days. During the 10 days, IgE was specifically secreted into the medium.

\section{Results and discussion}

Effects of human plasma and interleukins on human IgE induction

The necessity for inclusions of human plasma and interleukins was shown, when human lymphocytes and plasma from donors which were not naturally immunized with allergens were used. For the induction of IgE, human lymphocytes and plasma obtained from the same donor were required [2]. Addition of IL-2, 4 and 6 induced IgE. Elimination of each of these three interleukins from the medium resulted in no induction of $\operatorname{IgE}$ (data not shown). From these results, IL-2, 4 and 6 are considered to be essential factors to initially immunize lymphocytes with allergens, when lymphocytes and plasma from donors not naturally immunized with allergens were used. We next attempted to improve this system to stimulate IgE levels in the medium to provide a highly sensitive screening method.

\section{Effects of elimination of IL-2 from the medium on human IgE production}

In this study, the lymphocytes and plasma of donors naturally immunized with various allergens were used. Therefore, the IgE level of the control was high, i.e., more than $300 \mathrm{ng} / \mathrm{ml}$, as shown in Table 1. Elimination of IL-2 from the medium resulted in the induction of higher IgE levels compared with medium containing IL-2 (Table 1). These data indicate that elimination of IL-2 from the medium induced higher IgE levels when human lymphocytes and plasma obtained from naturally immunized donors were used. Furthermore, strawberry extract in the media containing Cryj1 and Derf2 decreased the secreted IgE levels by $38 \%$ and $24 \%$, respectively. There is a possibility that strawberries may alleviate allergies.

\footnotetext{
* Correspondence: hashizume.shu@nifty.com

${ }^{1}$ Idea-Creating Lab, Yokohama 236-0005, Japan

Full list of author information is available at the end of the article
} 
Table 1 Effects of various additives on IgE productivity

\begin{tabular}{ll}
\hline Medium & IgE productivity (ng/ml) \\
\hline Control (ERDF + hPlasma + FBS) & $319 \pm 19$ \\
\hline+ IL-2 + IL-4 + IL-6 + MDP + Cryj1 & $356 \pm 85$ \\
\hline+ IL-4 + IL-6 + MDP + Cryj1 & $549 \pm 189$ \\
\hline+ IL-4 + IL-6 + MDP + Cryj1 + strawberry extract & $341 \pm 55$ \\
\hline+ IL-4 + IL-6 + MDP + Derf2 & $660 \pm 172$ \\
\hline+ IL-4 + IL-6 + MDP + Derf2 + strawberry extract & $499 \pm 167$ \\
\hline
\end{tabular}

In summary, elimination of IL-2 from the IgE-inducing system medium increased the IgE induction level when human lymphocytes and plasma obtained from donors naturally immunized with allergens were used. The level of about $1 \mu \mathrm{g} / \mathrm{ml} \mathrm{IgE} \mathrm{reported} \mathrm{to} \mathrm{be} \mathrm{secreted} \mathrm{in} \mathrm{this}$ study may be the highest compared with those reported elsewhere. The original and improved systems for human IgE production are considered to be of profound use for studying allergy mechanisms and surveying allergyalleviating products, respectively.

\section{Authors' details}

${ }^{1}$ Idea-Creating Lab, Yokohama 236-0005, Japan. ${ }^{2}$ Kitakyushu National College

of Technology, Kitakyushu 802-0985, Japan.

Published: 4 December 2013

\section{References}

1. Kawahara $\mathrm{H}$, Maeda-Yamamoto M, Hakamata K: Effective induction and acquisition of human lgE antibodies reactive with house-dust mite extracts. J Immunol Methods 2000, 233:33-40.

2. Hashizume S, Kawahara H: Inducing of human IgE antibodies by in vitro immunization. In Proceedings of the 20th Annual Meeting of the European Society for Animal Cell Technology (ESACT). Springer Science+Business Media B.V;Noll T 2010:833-836, Dresden, Germany, 2007.

doi:10.1186/1753-6561-7-S6-O4

Cite this article as: Hashizume and Kawahara: Improvement in a human lgE-inducing system by in vitro immunization. BMC Proceedings 2013

7(Suppl 6):04.

\section{Submit your next manuscript to BioMed Central} and take full advantage of:

- Convenient online submission

- Thorough peer review

- No space constraints or color figure charges

- Immediate publication on acceptance

- Inclusion in PubMed, CAS, Scopus and Google Scholar

- Research which is freely available for redistribution

Submit your manuscript at www.biomedcentral.com/submit 